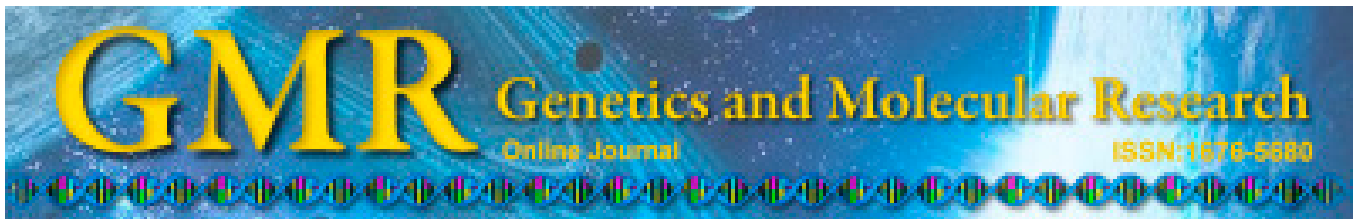

\title{
Abundance and diversity of sulfate-reducing bacteria in the sediment of the Zhou Cun drinking water reservoir in Eastern China
}

\author{
X. Yang ${ }^{1}$, T.L. Huang ${ }^{1}$, L. Guo ${ }^{1,2}$, C. Xia ${ }^{1}$, H.H. Zhang ${ }^{1}$ and S.L. Zhou ${ }^{1}$ \\ ${ }^{1}$ School of Environmental and Municipal Engineering, \\ Xi'an University of Architecture and Technology, Xi' an, Shaanxi, China \\ ${ }^{2}$ School of Environment and Planning, Liaocheng University, \\ Liaocheng, Shandong, China \\ Corresponding author: T.L. Huang \\ E-mail: huangtinglin@xauat.edu.cn
}

Genet. Mol. Res. 14 (2): 5830-5844 (2015)

Received December 1, 2014

Accepted April 28, 2015

Published May 29, 2015

DOI http://dx.doi.org/10.4238/2015.May.29.15

\begin{abstract}
Sulfate-reducing bacteria (SRB) play an important role in the sediments of bay areas, estuaries, and lakes. However, information regarding the genetic diversity of $\mathrm{SRB}$ in the sediments of drinking water reservoirs is scarce. In this study, we collected sediment samples from different sites in the Zhou Cun drinking water reservoir between April and June 2012. To explore the genetic diversity of SRB, we used the most-probable-number (MPN) method, polymerase chain reaction denaturing gradient gel electrophoresis (PCR-DGGE), and a cloning approach. The average content of acid-volatile sulfide at the deepest sampling site was $205.87 \mu \mathrm{g} / \mathrm{g}$ sediment. This result is often associated with a large abundance of SRB in the associated sediment. The highest MPN estimate $\left(1.15 \times 10^{5}\right.$ cells/g sediment $)$ was detected in May at the deepest sampling site. The PCR-DGGE fingerprints of SRB based on the dissimilatory sulfite reductase beta subunit $(d s r B)$ gene varied according to the different sampling sites and dates. The highest abundance of SRB in the sediments was predominantly found at the deepest sampling sites,
\end{abstract}


as expected from the acid-volatile sulfide content. The dominant species were Desulfobulbus sp, Desulfobacterium sp, and uncultured sulfatereducing bacteria. Redundancy analysis revealed that organic matter and the concentrations of nitrogen and phosphorus in the sediments were significantly correlated with the diversity of SRB communities present. The results of this study provide a better understanding of the sulfate-reducing microbial species in the sediments of the Zhou Cun drinking water reservoir.

Key words: Drinking water reservoir; Sulfate-reducing bacteria; Dissimilatory sulfite reductase beta subunit gene

\section{INTRODUCTION}

Freshwater from reservoirs is an important source of urban drinking water in China. Eutrofication or pollution of the water column could reduce the availability of water or even pose a serious hazard to human health. Sediments are thought to play a significant role in drinking water reservoirs because the sediments are closely related to freshwater quality through the deposition of material from the water column and the release of dissolved substances into the open water. The sediments of reservoirs are considerably different from those of other aquatic environmental ecosystems, as drinking water reservoirs generally have a shorter retention time of the water owing to a changing environment and heterogeneous habitats from the inflow to the main dam, and have sediment depths in accordance with vertical chemical gradients (Röske et al., 2012). Because of the sedimentation of material in reservoirs, decomposition within the sediments, and release of dissolved nutrients into the water resource, the sediments usually contain a vast number and diversity of microorganisms living under complex conditions. Microbial communities play a pivotal role in the flux of materials and are part of all major biogeochemical cycles through their involvement in the transformation of nitrogen, phosphorus, and sulfur (Lozupone and Knight, 2007). Hence, numerous studies have been performed to determine the microbial composition, based on 16S ribosomal RNA gene sequences, of the sediments in drinking water reservoirs and freshwater ponds (Peplies et al., 2006; Briée et al., 2007). These studies have suggested that the composition of microbial communities differs significantly between sampling sites with different environmental conditions. However, the metabolic and genetic characteristics of the functional microbial species residing in the sediments of drinking water reservoirs are not comprehensively understood.

Sulfate reduction is considered one of the most important processes for mineralization of organic matter $(\mathrm{OM})$ through the storage or release of hydrogen sulfide, which directly leads to electrochemical and anaerobic corrosion. Sulfate-reducing bacteria (SRB) were first isolated from production water in 1926 (Bastin et al., 1926), and SRB have since proven to be widespread in nature. Because of the ability to obtain energy from dissimilatory reduction of inorganic sulfate (Jørgensen, 1982), SRB have been considered key contributors in the sulfur cycle. Furthermore, SRB have the capacity to produce hydrogen sulfide that can react with heavy metal ions to form insoluble metal sulfides (Labrenz et al., 2000), and this metabolic activity can lead to biodegradation of organic pollutants such as cresol and biphenyl. These processes can contribute greatly to controlling the pollution in the water body. Owing to their great ecological and economic importance, SRB populations have been intensively studied 
during the last few decades using molecular techniques, including phylogenetic analysis, polymerase chain reaction denaturing gradient gel electrophoresis (PCR-DGGE), real-time PCR, and fluorescence in situ hybridization (FISH). Teske et al. (1998) used PCR-DGGE analysis to investigate the highly active SRB residing in Solar Lake, Egypt. Zhang et al. (2008) analyzed SRB communities in Victoria Harbor, Hong Kong, by using terminal restriction fragment length polymorphisms and found that the most diversified terminal restriction fragments were located at polluted sites. While many previous studies have shown that the SRB in the complex microbial communities of sediments are highly active, little is known in detail about the function of SRB in the sediments of drinking water reservoirs with their different environment structure.

As most SRB are difficult to cultivate, culture-independent methods have been widely used to assess the diversity of SRB. Although analysis based on the 16S rRNA gene might provide clues about the diversity of SRB, the application of functional gene analysis can provide more comprehensive and reliable information. The dissimilatory sulfite reductase beta subunit, which catalyzes the reduction of sulfite to sulfide, is encoded by the $d s r B$ gene and is required by all sulfate reducers (Wagner et al., 1998). The $d s r B$ gene is the best-studied example of a key functional marker for the molecular analysis and detection of SRB.

The Zhou Cun drinking water reservoir came into operation in 1959 and was used as a fish farm during the 1980s and 1990s (Cheng et al., 2010). Hence, the sediments in the reservoir receive a large amount of organic waste from uneaten food and fecal material. This organic pollution reduces the amount of dissolved oxygen at the bottom of the reservoir and causes sulfide to accumulate in the sediments. In this study, we hypothesized that SRB communities in the drinking water reservoir would differ with sampling sites and dates. Therefore, several sampling sites were selected along the gradient with the deepest site in front of the dam, and were sampled on different dates. Selected properties of the sediments were analyzed. SRB counts in the sediment samples were estimated by the most-probable-number (MPN) method, and the sulfate reduction activities of the samples were measured. PCR-DGGE analysis and clone libraries were used to characterize the sediment SRB based on the $d s r B$ gene. In this study, our specific objectives were to 1) evaluate the diversity of SRB communities in the sediments of the Zhou Cun reservoir, eastern China, and 2) investigate the relationship between the composition of the SRB communities and the physicochemical factors of the sediments.

\section{MATERIAL AND METHODS}

\section{Study sites and sediment sampling}

The Zhou Cun drinking water reservoir is located at Zhou Cun $\left(34^{\circ} 56^{\prime} \mathrm{N}-34^{\circ} 57^{\prime} \mathrm{N}\right.$, $\left.117^{\circ} 39^{\prime} \mathrm{E}-117^{\circ} 41^{\prime} \mathrm{E}\right)$, near the city of Zaozhuang in the Shandong Province in eastern China. The reservoir has four tributaries with a surface area of $121 \mathrm{~km}^{2}$ and a volume of 84 million $\mathrm{m}^{3}$ at full water level. The maximum depth of the reservoir is $20 \mathrm{~m}$ and the mean depth is 10 $\mathrm{m}$. During the summer, the water body is thermally stratified (Cao et al., 2013).

Six sampling sites were chosen along the flow of water and matter, starting at the prereservoir $2500 \mathrm{~m}$ upstream of the main dam, spanning the main reservoir along a distance of $500 \mathrm{~m}$, and ending in front of the dam (Figure 1). The third to the sixth sampling sites were located in the main reservoir with an average water depth of $15 \mathrm{~m}$, approximately $10 \mathrm{~m}$ deeper than the sites in the pre-reservoir. A Petersen stainless steel grab sampler was used to collect the samples, and the Ashtech Global Positioning System (Huace Company, Shanghai, China) 
was used to locate the sampling positions (Zhang et al., 2013). The coordinates and depths of the six sampling site are presented in Table 1. At each site, samples were collected from the top $30 \mathrm{~cm}$ layer of sediments (Zhu et al., 2010). Three sampling dates were chosen in the months of April, May, and June 2012, respectively, during which time the water temperature continuously increased after the winter period. A total of 15 sediment samples were collected. All the samples from the main reservoir appeared black in color with a noticeable smell of hydrogen sulfide. Samples were then divided into two parts. One part was used for MPN counts immediately; the other part was placed in sterilized bottles, sealed, and immediately transported to the laboratory in a cool box and stored at $-20^{\circ} \mathrm{C}$.

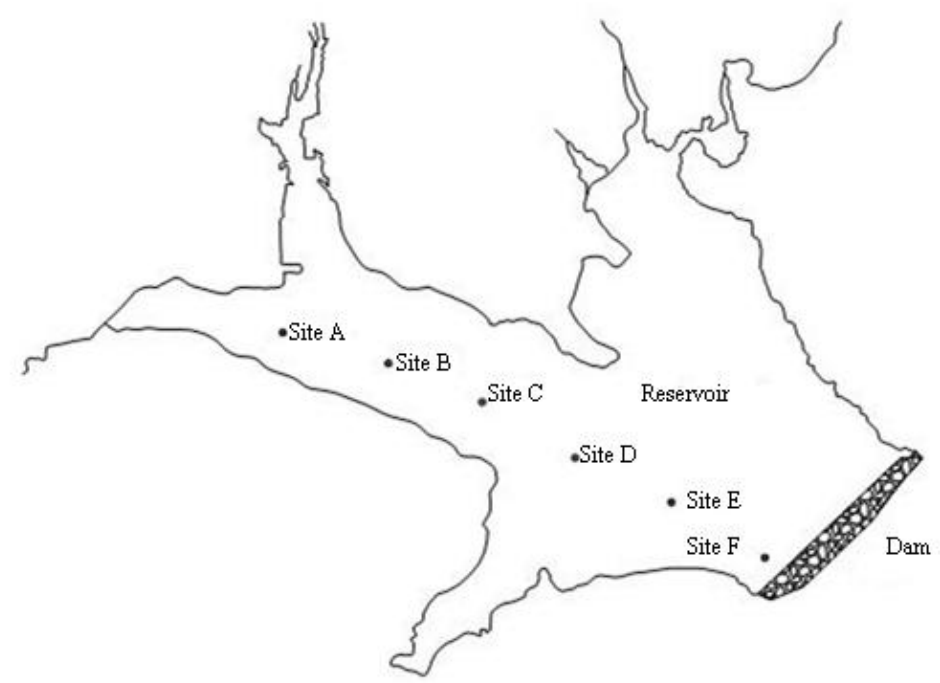

Figure 1. Schematic representation of the Zhou Cun drinking water reservoir, Eastern China. Dots represent the six sampling sites A-F.

\section{Analysis of sediment chemical characteristics}

For chemical analyses, each sediment sample was homogenized. The $\mathrm{pH}$ of the sediment pore water was measured using a portable HQ11d pH/ORP Meter (Hach Co., Loveland, $\mathrm{CO}$, USA). The samples were dried at $105^{\circ} \mathrm{C}$ for $8 \mathrm{~h}$ to determine the dry weight according to German standards (DIN 38414-S2). The OM was determined as dry weight loss (\%) after ignition at $550^{\circ} \mathrm{C}$ for $2 \mathrm{~h}$ (DIN 38414-S3). Acid-volatile sulfide (AVS) was extracted by exposure the wet samples to concentrated hydrochloric acid by using steam distillation and was trapped in a solution of sodium hydroxide and ethylenediaminetetraacetic acid (EDTA). The trapped sulfides were measured using a DR 5000 spectrophotometer (Hach Co.) (Röske et al., 2008; Kondo et al., 2012). The sulfate concentrations of the samples were measured by ion chromatography (Metrohm AG, Herisau, Switzerland). For determination of the total N (TN) and total P (TP), the samples were dried at $50^{\circ}-60^{\circ} \mathrm{C}$ overnight and kept in a vacuum until analysis. Subsamples were then prepared by microwave digestion and measured at $543 \mathrm{~nm}(\mathrm{TN})$ and $420 \mathrm{~nm}$ (TP) using a DR 5000 spectrophotometer (Hach Co.) (McGill and Figueiredo, 1993; Xia et al., 2011). 


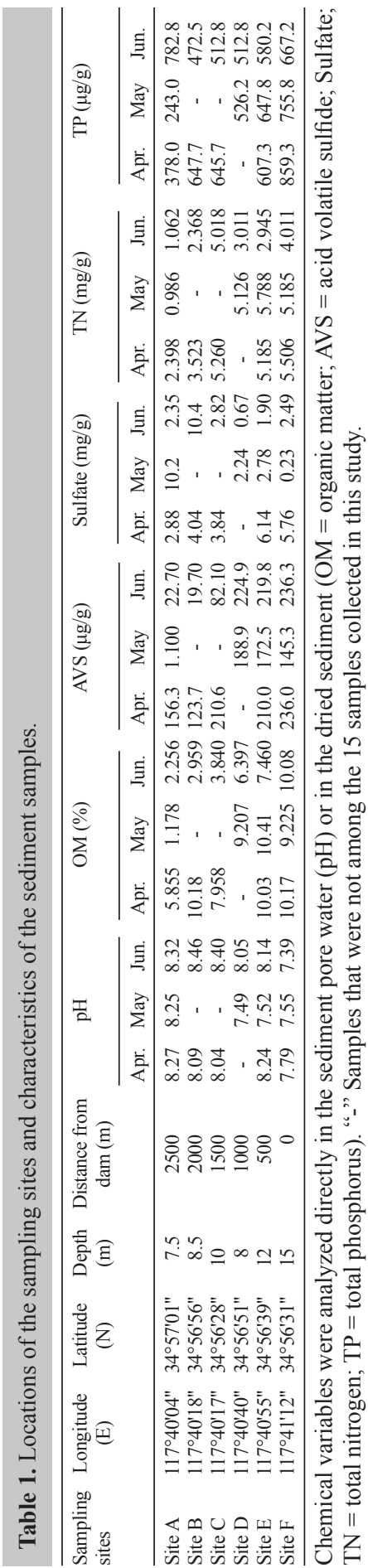




\section{SRB abundance}

The SRB in the sediment samples were counted using the MPN method as previously described (Teske et al., 1998). Sediments from Site F which is the deepest sampling site collected at different dates were homogenized into three subsamples (April, May, and June), respectively. Triplicate MPN dilution series for each subsample were prepared by inoculating $1 \mathrm{~g}$ subsample into $9 \mathrm{~mL}$ sterile distilled water, diluting the solution by a factor of 1:10 eight times, and placing each dilution in a rapid test tube (Huaxing Company, Beijing, China). The test tubes were sealed and cultured at $37^{\circ} \mathrm{C}$ for 14 days. MPNs were scored as positive when black deposits were produced in the tubes. Standard MPN evaluation tables and 95\%CIs were used (Eaton et al., 2005).

\section{DNA extraction, PCR amplification, and DGGE}

Microbial DNA was extracted from the sediment samples using the Soil DNA Extraction Kit (Omega Bio-Tek, Norcross, GA, USA) following the manufacturer instructions. The quality of the extracted DNA was assessed by performing electrophoresis on $1 \%$ weight per volume (w/v) agarose gels stained with GelRed (Biotium, Hayward, CA, USA).

The primer DSRp2060F (5'-CAA CAT CGT YCA YAC CCA GGG-3') (Geets et al., 2006), containing a 40-bp GC-clamp (CGC CCG CCG CGC CCC GCG CCC GGC CCG CCG CCC CCG CCC C) at the 5'-end, was used in combination with the primer DSR4R (5'-GTG TAG CAG TTA CCG CA-3') (Wagner et al., 1998) for PCR amplification of the full-length $d s r B$ gene. Amplification was performed in a 50- $\mu \mathrm{L}$ reaction volume containing $1 \mu \mathrm{L}$ DNA, $0.5 \mu \mathrm{L}$ of each primer, $25 \mu \mathrm{L}$ PCR Mix Buffer (Kangwei Century Company, Beijing, China), and $23 \mu \mathrm{L}$ deionized water. PCR was performed in a C1000 thermal cycler (Bio-Rad Laboratories, Berkeley, CA, USA) using the following cycling conditions: initial denaturation at $94^{\circ} \mathrm{C}$ for $4 \mathrm{~min} ; 35$ cycles of denaturation at $94^{\circ} \mathrm{C}$ for $1 \mathrm{~min}$, annealing at $52^{\circ} \mathrm{C}$ for $1 \mathrm{~min}$, and extension at $72^{\circ} \mathrm{C}$ for $1 \mathrm{~min}$; and a final extension at $72^{\circ} \mathrm{C}$ for $10 \mathrm{~min}$. Under these conditions, a single PCR product of $350 \mathrm{bp}$ was obtained and examined by electrophoresis on a $1 \%(\mathrm{w} / \mathrm{v})$ agarose gel that was stained using GelRed and photographed under ultraviolet (UV) light on a Gel Doc XR+ Image Lab System (Bio-Rad). The PCR products were stored at $-20^{\circ} \mathrm{C}$ for subsequent DGGE analysis.

The PCR products were analyzed by DGGE fingerprinting using a DCode system (Bio-Rad). For each sample, $45 \mu \mathrm{L}$ PCR product was mixed with $5 \mu \mathrm{L}$ loading buffer (Kangwei Century Co.). Acrylamide gels [ $8 \%(\mathrm{w} / \mathrm{v})$; acrylamide- $N, N^{\prime}$-methylenebisacrylamide ratio, $37.5: 1$ ] with a denaturing gradient ranging from $30-70 \%(\mathrm{w} / \mathrm{v})$ [where $100 \%(\mathrm{w} / \mathrm{v})$ denaturant corresponded to $7 \mathrm{M}$ urea and $40 \%$ (v/v) formamide] were used for the analysis. Electrophoresis was carried out for $13 \mathrm{~h}$ at a constant voltage of $70 \mathrm{~V}$ at $58^{\circ} \mathrm{C}$ in tris-acetate-EDTA buffer (40 mM Tris, $20 \mathrm{mM}$ acetic acid, and $1 \mathrm{mM}$ EDTA; pH 8.0). After electrophoresis, the gels were stained using GelRed for $20 \mathrm{~min}$ and photographed under UV light. The banding patterns of the DGGE fingerprints were analyzed using the Quantity One software (Version 4.5, Bio-Rad). The peak density (relative intensity) of each gel band was recorded for redundancy analysis (RDA) (Zhang et al., 2013).

\section{Construction of clone libraries and phylogenetic analysis}

The DNA bands of interest were excised from the DGGE gels and eluted in $30 \mu \mathrm{L}$ 
deionized water for $24 \mathrm{~h}$ at $4^{\circ} \mathrm{C}$. The eluate was re-amplified using PCR with the primers DSRp2060F (without the GC-clamp) and DSR4R under the conditions as described above. The PCR products were purified using a purification kit (BioTeke Company, Beijing, China) following the manufacturer instructions. To construct clone libraries of SRB, the purified PCR products were cloned into the pMD18T vector (TaKaRa, Osaka, Japan) at $16^{\circ} \mathrm{C}$ overnight and transformed into One Shot TOP10 chemically competent Escherichia coli DH5 $\alpha$ cells (Tiangen Company, Beijing China) according to manufacturer instructions (Liu et al., 2009, Guan et al., 2013a). The transformed cells were plated on Luria broth (LB) agar plates containing ampicillin. After plating, positive transformants in each library were randomly selected and screened for inserts by PCR amplification using the primers DSRp2060F and DSR4R, cultured at $37^{\circ} \mathrm{C}$ overnight in tubes containing $\mathrm{LB}$ broth, and sending for sequencing by an $\mathrm{ABI}$ automated sequencer (Sangon Biotech Company, Shanghai, China). Clones without inserts or those containing incorrectly sized inserts were excluded from sequencing. A total of 19 clones were sequenced. All sequences were deposited in GenBank under the accession Nos. KF916017-KF916035.

The $d s r B$ gene sequences were translated into amino acid sequences using the Sequin tool (National Center for Biotechnology Information). The clone sequences and the deduced amino acid sequences were compared with sequences in the GenBank database using the basic local alignment search tool (BLAST) (Altschul et al., 1997). The $d s r B$ sequences and their closest homologs in GenBank, as detected by BLAST, were aligned using the ClustalW program. Phylogenetic trees were constructed by the neighbor-joining method (Saitou and Nei, 1987) based on the Jukes-Cantor distance model using the MEGA software (Version 5.05) (Tamura et al., 2011). A total of 1000 bootstrap replications were assessed.

\section{Statistical analysis}

RDA was employed to identify potential main factors that might affect the DGGE profiles. The DGGE fingerprinting data and environment variables were correlated using the Canoco software (version 4.5) and CanoDraw (Zhang et al., 2013). To analyze the relationships between environment variables and variation in the DGGE band data, RDA ordination axes were constrained to linear combinations of physicochemical properties of sediments.

\section{RESULTS AND DISCUSSION}

\section{Sediment chemical characteristics}

The chemical characteristics of the sediments analyzed in this study are summarized in Table 1. The sampling sites showed a noticeable increase in both OM and AVS content with the increasing water depth from the pre-reservoir to the main reservoir. The content of OM in sediments that had black color and hydrogen sulfide smell were markedly higher than the others. This organic enrichment of sediments in the main reservoir was likely a result of the accumulation of sulfide from a large amount of organic waste due to uneaten food and fecal material. Interestingly, however, in the pre-reservoir, the OM and AVS contents from sites A, $\mathrm{B}$, and $\mathrm{C}$ were remarkably higher in April than in May and June. The inflows of the Zhou Cun drinking water reservoir started to rebound at the beginning of May in 2012, influenced by the rising temperature after the winter period. The increasing inflow of water led to resuspension 
of organic material, followed by rapid reduction of OM and AVS contents in the pre-reservoir, which was shallower than the main reservoir. Conversely, the water body of the main reservoir became thermally stratified, and the inflows and the internal waves in the main reservoir did not greatly influence the sediment transport. In addition, the dam walls in front of site F led to enhanced sedimentation. Because site $\mathrm{F}$ was the deepest point, the accumulation of sediments was already most pronounced there. Therefore, the highest average OM content and the maximum value of AVS were observed at site F. Furthermore, the average AVS value at site F was $205.87 \mu \mathrm{g} / \mathrm{g}$ sediment, which was much higher than the corresponding value observed in our previous study of other drinking water reservoirs and very similar to the reference data for deep sea sediments (Zhou et al., 2009; Zhang et al., 2012; Gao et al., 2013). These results suggest the potential for sulfate reduction processes to play a more important role in main reservoirs with a higher depth. In our previous study, we also found that the dissolved oxygen at the bottom of the reservoir had been depleted to zero, and that the negative redox potentials were in the range of 100-200 $\mathrm{mV}$, suggesting that the sediments of the main reservoir might have favorable conditions for sulfate reduction.

The $\mathrm{pH}$ values of the sediments varied between 7.3 and 8.5 (Table 1). The values decreased with the increasing depth from the pre-reservoir to the main reservoir, consistent with the fact that sulfate reduction processes can reduce the $\mathrm{pH}$. The average $\mathrm{pH}$ value of the May samples was lower than the $\mathrm{pH}$ values of the April and June samples. Sulfate was present in all samples but at different concentrations. The TN and TP concentrations also increased from the pre-reservoir to the main reservoir. The average concentrations of TN and TP compared with the reference indicated that the sediments of the Zhou Cun drinking water reservoir were affected by internal eutrophication. Under anaerobic conditions, especially in the hypolimnion during the stratification period, the release of nutrients such as $\mathrm{N}$ and $\mathrm{P}$ would be increasing, which could intensify the deterioration of the water quality of the reservoir. Our results indicated that the sediments of the Zhou Cun drinking water reservoir were heavily polluted by fish farming. However, more seasonal data regarding chemical components, recorded over several years, are needed to investigate the relationship between the shifts in the reservoir sediments and the spatial heterogeneity and temporal changes.

\section{SRB abundance}

A SRB count of approximately $4.5 \times 10^{4}$ cells $/ g$ sediment was estimated from the samples taken in April from Site F. The estimated SRB count increased to $1.15 \times 10^{5}$ cells $/ \mathrm{g}$ in May and decreased to $1.35 \times 10^{4}$ cells/g in June collected from Site F. The significant increase in SRB from April to May was likely due to the water body of the reservoir becoming thermally stratified in early May, producing a longitudinal gradient of dissolved oxygen. The concentration of dissolved oxygen at the bottom of the water was sharply reduced from 5.34 $\mathrm{mg} / \mathrm{L}$ to zero during the 27 days from April 27 to May 23. However, the reason for the pronounced reduction in SRB from May to June is still unknown.

The MPN estimates of SRB were lower than those reported for the Solar Lake in Egypt (Teske et al., 1998). The freshwater habitat of the Zhou Cun drinking water reservoir showed similar relative abundance of SRB as do marine sediments (Ramsing et al., 1993). Our results indicated that this was due to the accumulation of nutrients from fish farming, which produced similar environmental conditions in the sediments as those in marine sediments. 


\section{SRB community composition}

To reveal the microbial community structure of the SRB, we employed a DGGE approach. Additionally, DNA sequence information was obtained from recovered gel bands. The DGGE profiles are shown in Figure 2. The results suggested that SRB were present at high abundance in the Zhou Cun drinking water reservoir, and the samples collected at different times and sites differed in the number, position, and brightness of the DGGE bands. There were 65 varieties of conspicuous bands in the profiles. Sample E6 (site E, June), collected at the second deepest site, was the most diverse sample with the highest number of bands, whereas sample D4 (site D, April) was the least diverse. The analysis of DGGE banding patterns showed 12 groups of lanes with more than $50 \%$ similarity. The highest similarity was $69.7 \%$ between sample C4 (site C, April) and sample E4 (site E, April), which were collected from similar sites at the same time. The lowest similarity was $20.0 \%$ between sample A4 (site A, April) and sample F6 (site F, June), consistent with the largest difference in both sampling site and time. These results suggested that the structure of SRB communities could be divided into two categories. The first category included all the samples collected in April and some of the samples collected in May. After this time point, thermal stratification in the reservoir appeared to alter the composition and diversity of the SRB communities. Consequently, the second category included all the samples collected in June and some of the samples collected in May. At this stage, the diversity of SRB was inconspicuously affected by the sampling location.

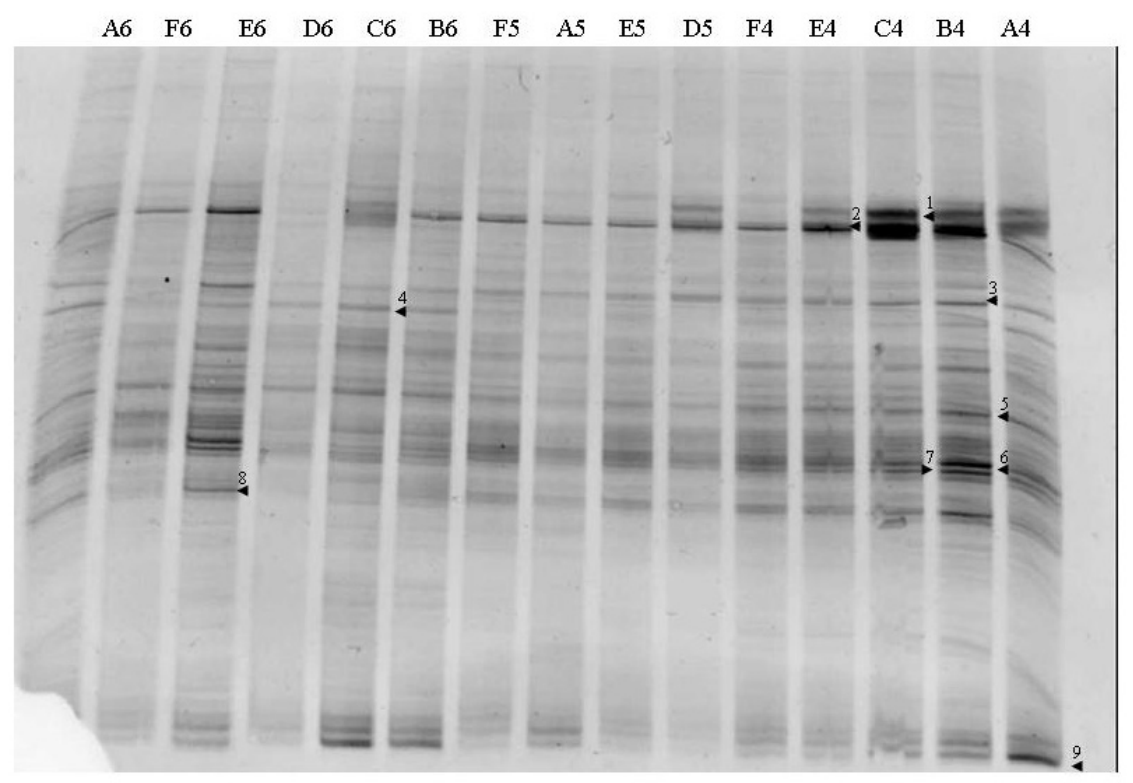

Figure 2. DGGE-profile of the PCR-amplified $d s r B$ genes recovered from the Zhou Cun drinking water reservoir sediment samples. Fragments were run on a 30 to $70 \%$ denaturing gradient gel. The bands indicated by numbers 1-9 were excised from the DGGE gels. The lane letters and numbers refer to the sample sites and months of collection, respectively (e.g. A6 represents a replicate of the sample retrieved from site A in June). The samples D4, B5, and C5 were not among the 15 samples collected in this study. DGGE = denaturing gradient gel electrophoresis; $\mathrm{PCR}=$ polymerase chain reaction. 
Combined with the physicochemical properties of the sediment samples described above, RDA of the DGGE profiles was used to examine the relationship between SRB diversity and environmental variables (Figure 3 ). The results suggested that the $\mathrm{pH}$ and AVS were positively correlated with SRB species diversity while the other environmental variables correlated negatively. At this stage, the OM most significantly affected the structural diversity of the SRB communities. In the drinking water reservoir, the input of OM in the water body was limited. Hence, the decomposition of $\mathrm{OM}$ in the sediments was dominated by sulfate reduction and the SRB relied on the OM in the sediment as their carbon source. Furthermore, sediment microbes make important contributions to the nutrient cycling in ecosystems. Consequently, TN and TP were also strongly correlated with SRB diversity. It should be noted that an increased abundance of SRB was expected but not observed in the sediment samples with reduced sulfate concentrations. A similar negative correlation has been reported by Schippers and Neretin (2006), suggesting that SRB rely on the availability of sulfate but do not belong to the most abundant bacterial groups, even in environments with high sulfate concentrations.

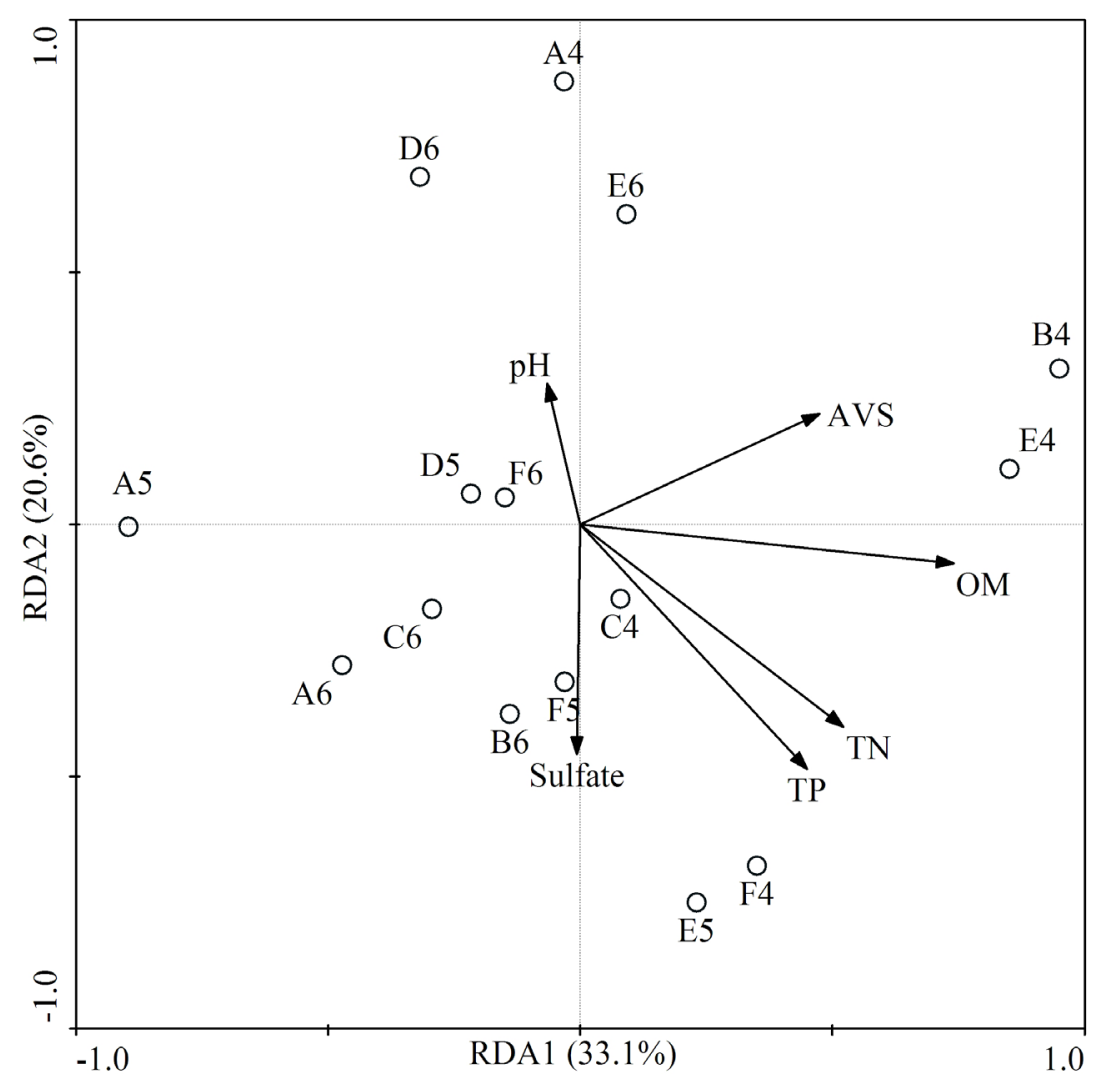

Figure 3. Redundancy analysis (RDA) between the SRB community and chemical (environmental) components. Samples are represented by open circles, and the letters and numbers refer to the sampling sites and months. In the $\mathrm{x}$ - and $\mathrm{y}$-axes legends, the numbers in parentheses represent the percentage of variation of the data explained by each factor. The primary factors for the variables of the environmental data are represented by arrows. SRB = sulfate-reducing bacteria. 
The RDA results might provide insights on how to control the SRB abundance and improve the water quality of the Zhou Cun drinking water reservoir. Comparatively, waterlifting and aeration technology for in situ restoration of water quality has been applied successfully to a reservoir in northern China (Cong et al., 2009). Under the mixing and aeration conditions used, the thermal stratification structure was disturbed and the concentration of dissolved oxygen (DO) was raised by $2-3 \mathrm{mg} / \mathrm{L}$, which led to a reduced release of ammonia$\mathrm{N}$ and $\mathrm{P}$ from the sediments into the water. Most importantly, the increasing DO combined with improved redox conditions would be expected to inhibit sulfate reduction and reduce the release of hydrogen sulfide. Alternatively, considering the high OM and AVS content in the sediment of Zhou Cun reservoir, sediment dredging could be an effective way to control internal pollution.

\section{Phylogenetic analysis of clone library}

Nine specific bands were excised from the DGGE gel (Figure 2). Some bands excised from the same position in the gel had different sequences, and a total of 19 clones were sequenced. As shown in Table 2, BLAST analysis revealed that $100 \%$ of these sequences were affiliated with as yet uncultured organisms obtained from various environments: the Guaymas Basin (Dhillon et al., 2003), the Changjiang Estuary (He et al., unpublished data), and saline lakes (Yang et al., unpublished data). The similarities between the 19 clones and their best matches from the BLAST analysis varied from 80 to $99 \%$. Clone YX2-5, obtained from band 2 (observed in all DGGE lanes), was $99 \%$ identical to a sequence from a species detected in groundwater polluted by landfill leachate (Wu et al., 2009), defined as an uncultured sulfatereducing bacterium. Clones YX1-3, YX4-9, and YX6-13, obtained from bands 1, 4, and 6, respectively (observed in several lanes), were identical to uncultured prokaryote clones obtained from fen soil (Loy et al., 2004) and mangrove sediments (Lopez et al. unpublished data), respectively. Therefore, these sequences could not be assigned to particular species. The clone YX5-10 was 95\% similar to an uncultured Desulfobulbus sp clone (Oakley et al., 2010) found in estuarine sediment. According to our phylogenetic analysis, 10 clones were very similar to each other and clustered into a main group of Desulfobacterium sp, and were found to be closely related to sequences retrieved from an oil field (Guan et al., 2013b). Both Desulfobulbus sp and Desulfobacterium sp belong to the Desulfobacteraceae family, whose members play an important role in the production of sulfide along coastal seas. However, being partially oxidative species, Desulfobulbus propionicus, Desulfobacterium autotrophicum, and other SRB such as Desulfococcus multivorans can switch from sulfate reduction to aerobic respiration as soon as they are exposed to low concentrations of oxygen; they are therefore also found in limnic environments (Dilling and Cypionka, 1990; Kondo and Butani, 2007). The rest of the sequences in the phylogenetic tree were distant from recognized species, with several clones closely related to sequences retrieved from fish farms, saline lakes, and soil (Figure 4).

As mentioned above, our study provides a valuable first insight into the structural diversity of SRB communities in sediments of the Zhou Cun drinking water reservoir. The results presented here were consistent with previous studies indicating that the Desulfobacteraceae and Desulfobulbaceae families mainly dominated the known SRB groups, but a significant number of clones were of unknown affiliation. The SRB species in the Zhou Cun reservoir might have originated from bacteria in feces deposited by fish. Although few of the reference sequences were obtained from freshwater sediments, our results most likely re- 
flected the similar redox conditions in sediment under anaerobic environments. Furthermore, some of the deduced amino acid sequences encoded by the $d s r B$ gene in SRB from the Zhou Cun reservoir were reported for the first time in this study. However, the metabolic characteristics of the uncultured species detected in this study have not yet been elucidated. Hence, new culture strategies might be needed for further studies.

\begin{tabular}{|c|c|c|c|c|}
\hline Clone library & $\begin{array}{c}\text { DGGE } \\
\text { band No. }\end{array}$ & $\begin{array}{l}\text { Sequence } \\
\text { size (bp) }\end{array}$ & Closest related organism in the database (GenBank accession No.) & $\begin{array}{c}\text { Similarity } \\
(\%)\end{array}$ \\
\hline YX1-1 & 1 & 343 & Uncultured sulfate-reducing bacterium clone B03P021 (AY197440.1) & 94 \\
\hline YX1-2 & 1 & 340 & Uncultured sulfate-reducing bacterium isolate DGGE gel band EHLS-05 (JQ742051.1) & 94 \\
\hline YX1-3 & 1 & 322 & Uncultured prokaryote clone $d s r$ SbI-66 (AY167480.1) & 80 \\
\hline YX2-4 & 2 & 331 & Uncultured sulfate-reducing bacterium clone CJK02031 (KC865383.1) & 96 \\
\hline YX2-5 & 2 & 343 & Uncultured sulfate-reducing bacterium isolate DGGE gel band 10 (EF064999.1) & 99 \\
\hline YX3-6 & 3 & 340 & Uncultured sulfate-reducing bacterium clone G-48 (DQ250769.1) & 92 \\
\hline YX3-7 & 3 & 331 & Uncultured sulfate-reducing bacterium isolate DGGE gel band GHL2S-23 (JQ742069.1) & 87 \\
\hline YX4-8 & 4 & 322 & Uncultured bacterium isolate OL-KR49_415-419m_dsrB_10 (FR871745.1) & 92 \\
\hline YX4-9 & 4 & 322 & Uncultured prokaryote clone Bu-22 (JN6 15147.1$)$ & 88 \\
\hline YX5-10 & 5 & 340 & Uncultured Desulfobulbus sp clone S10_33 (FJ544728.1) & 95 \\
\hline YX5-11 & 5 & 322 & Uncultured bacterium isolate DGGE gel band RTG_SRB_7 (HQ690812.1) & 89 \\
\hline YX6-12 & 6 & 343 & Uncultured bacterium clone: yat226 (AB632236.1) & 84 \\
\hline YX6-13 & 6 & 322 & Uncultured prokaryote clone AntMgv_09(KC107326.1) & 93 \\
\hline YX7-14 & 7 & 322 & Uncultured sulfate-reducing bacterium isolate DGGE gel band HR1E (HQ413120.2) & 92 \\
\hline YX7-15 & 7 & 322 & Uncultured sulfate-reducing bacterium isolate DGGE gel band HR5G (HQ413133.2) & 96 \\
\hline YX8-16 & 8 & 331 & Uncultured bacterium clone: yat032 (AB632042.1) & 98 \\
\hline YX8-17 & 8 & 322 & Uncultured sulfate-reducing bacterium isolate DGGE gel band HR4D (HQ413129.2) & 90 \\
\hline YX9-18 & 9 & 322 & Uncultured sulfate-reducing bacterium clone VO10 (AY953413.1) & 94 \\
\hline YX9-19 & 9 & 328 & Uncultured sulfate-reducing bacterium clone OTU-97 (EU258867.1) & 83 \\
\hline
\end{tabular}

DGGE $=$ denaturing gradient gel electrophoresis.

In this study, we estimated the diversity and distribution of SRB communities in sediments from the Zhou Cun drinking water reservoir. Sediment samples retrieved from several sites with different environmental conditions had different physicochemical properties including OM content and nutrient concentrations. As expected, the nutrient concentrations increased from the pre-reservoir to the main reservoir. The remarkably high sulfide concentration and OM content were comparable to data from marine or deep sea sediments. Both MPN and PCR-DGGE methods indicated a high abundance of SRB. Furthermore, the PCR-DGGE method revealed differences in the genetic diversity of SRB communities between the samples based on their $d s r B$ gene. Comparison of the communities detected in our study was feasible since all samples were treated similarly. The results also suggested that Desulfobulbus sp and Desulfobacterium sp were the dominant species in the sediments. However, the sediments also harbored a vast number of uncultured and unclassified bacteria. Consequently, a large number of bacteria could not be classified below the family level and their metabolic capabilities remain unknown. The OM content as well as $\mathrm{N}$ and $\mathrm{P}$ concentrations were significantly correlated with the SRB community composition.

Although some progress has been made in this study, the seasonal shifts in both the abundance of SRB and the environmental chemistry need to be analyzed over several more years to identify possible reasons for the SRB community variation. New techniques, including microarray and high-throughput pyrosequencing, are also needed in the future. Furthermore, the differences in the SRB communities of the reservoir sediments reflect the different 
physicochemical properties at the selected sites. Therefore, SRB might be used as a statistically significant biological indicator to assess pollution levels in sediments of the Zhou Cun drinking water reservoir.

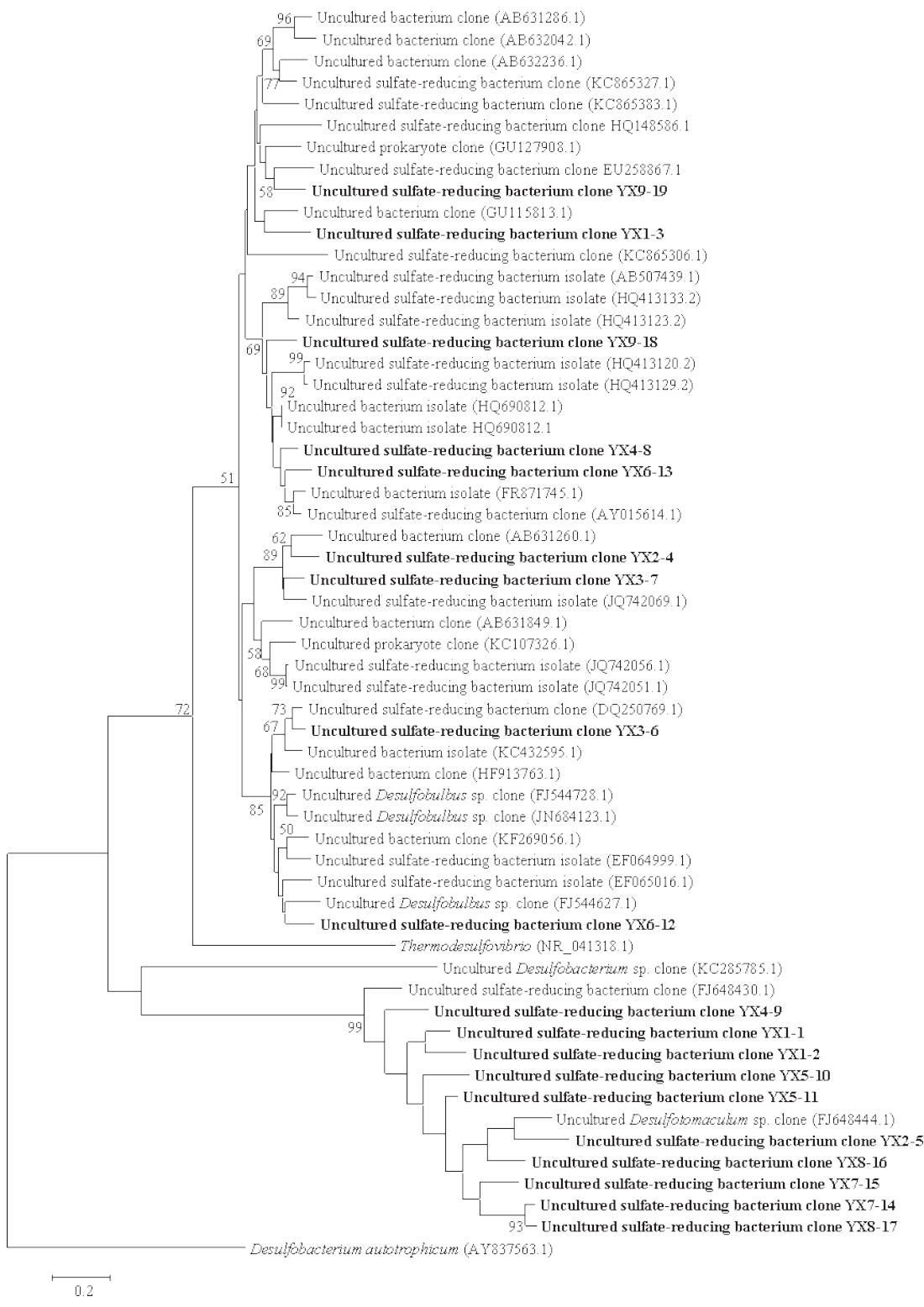

Figure 4. Phylogenetic affiliations of $d s r B$ gene sequences retrieved from sediment sulfate-reducing bacterial communities. This phylogenetic tree was generated using the neighbor-joining method. Bootstrap values $(>50 \%)$ are indicated at nodes (1000 replications). Sequences obtained in the present study are shown in boldface. Accession numbers are given in brackets. Desulfobacterium autotrophicum was included as an outgroupto root the tree. The scale bar represents 0.2 substitutions per nucleotide position. 


\section{Conflicts of interest}

The authors declare no conflict of interest.

\section{ACKNOWLEDGMENTS}

Research supported by the National Science and Technology Pillar Program of China (\#2012BAC04B02). We thank the administration of the Zhou Cun drinking water reservoir for help with the sediment sampling.

\section{REFERENCES}

Altschul SF, Madden TL, Schäffer AA, Zhang J, et al. (1997). Gapped BLAST and PSI-BLAST: a new generation of protein database search programs. Nucleic Acids Res. 25: 3389-3402.

Bastin ES, Greer FE, Merritt C and Moulton G (1926). The presence of sulphate reducing bacteria in oil field waters. Science 63: 21-24.

Briée C, Moreira D and López-Garcia P (2007). Archaeal and bacterial community composition of sediment and plankton from a suboxic freshwater pond. Res. Microbiol. 158: 213-227.

Cao ZH, Huang TL, Qiu XP and Shi JC (2013). Simulation of potential release of sediment pollutants at Zhoucun Reservoir. Env. Sci. Technol. 36: 41-44.

Cheng SZ, Xu SJ and Diao HW (2010). Influence of fish culturing with cages in reservoir on water quality and countermeasures to it (in Chinese). J. Water Resour. Architect. Eng. 8: 30-31.

Cong HB, Huang TL, Chai BB and Zhao JW (2009). A new mixing-oxygenating technology for water quality improvement of urban water source and its implication in a reservoir. Renewable Energy 34: 2054-2060.

Dhillon A, Teske A, Dillon J, Stahl DA, et al. (2003). Molecular characterization of sulfate-reducing bacteria in the Guaymas Basin. Appl. Environ. Microbiol. 69: 2765-2772.

Dilling W and Cypionka H (1990). Aerobic respiration in sulfate-reducing bacteria. FEMS Microbiol. Lett. 71: 123-127.

Eaton AD, Clesceri LS, Rice EW, Greenberg AE, et al. (eds.) (2005). Standard methods for the examination of water and wastewater. American Public Health Association, Washington.

Gao X, Li P and Chen CT (2013). Assessment of sediment quality in two important areas of mariculture in the Bohai Sea and the northern Yellow Sea based on acid-volatile sulfide and simultaneously extracted metal results. Mar. Pollut. Bull. 72: 281-288.

Geets J, Borremans B, Diels L, Springael D, et al. (2006). DsrB gene-based DGGE for community and diversity surveys of sulfate-reducing bacteria. J. Microbiol. Methods 66: 194-205.

Guan J, Xia LP, Wang LY, Liu JF, et al. (2013a). Diversity and distribution of sulfate-reducing bacteria in four petroleum reservoirs detected by using 16S rRNA and dsrAB genes. Int. Biodeterior. Biodegrad. 76: 58-66.

Guan J, Zhang BL, Mbadinga SM, Liu JF, et al. (2013b). Functional genes (dsr) approach reveals similar sulphidogenic prokaryotes diversity but different structure in saline waters from corroding high temperature petroleum reservoirs. Appl. Microbiol. Biotechnol. 98: 1871-1872.

Jørgensen BB (1982). Mineralization of organic-matter in the sea bed-the role of sulfate reduction. Nature 296: 643-645.

Kondo R and Butani J (2007). Comparison of the diversity of sulfate-reducing bacterial communities in the water column and the surface sediments of a Japanese meromictic lake. Limnology 8: 131-141.

Kondo R, Mori Y and Sakami T (2012). Comparison of sulphate-reducing bacterial communities in Japanese fish farm sediments with different levels of organic enrichment. Microbes Environ. 27: 193-199.

Labrenz M, Druschel GK, Thomsen-Ebert T, Gilbert B, et al. (2000). Formation of sphalerite (ZnS) deposits in natural biofilms of sulfate-reducing bacteria. Science 290: 1744-1747.

Liu XZ, Zhang LM, Prosser JI and He JZ (2009). Abundance and community structure of sulfate reducing prokaryotes in a paddy soil of southern China under different fertilization regimes. Soil Biol. Biochem. 41: 687-694.

Loy A, Küsel K, Lehner A, Drake HL, et al. (2004). Microarray and functional gene analyses of sulfate-reducing prokaryotes in low-sulfate, acidic fens reveal cooccurrence of recognized genera and novel lineages. Appl. Environ. Microbiol. 70: 6998-7009.

Lozupone CA and Knight R (2007). Global patterns in bacterial diversity. Proc. Nat. Acad. Sci. U.S.A. 104: 11436-11440. McGill WB and Figueiredo CT (1993). Total nitrogen. In: Soil sampling and methods of analysis (Carter MR, ed.). Lewis 
Publ., Boca Raton, 201-211.

Oakley BB, Carbonero F, van der Gast CJ, Hawkins RJ, et al. (2010). Evolutionary divergence and biogeography of sympatric niche-differentiated bacterial populations. ISME J. 4: 488-497.

Peplies J, Lachmund C, Glöckner FO and Manz W (2006). A DNA microarray platform based on direct detection of rRNA for characterization of freshwater sediment-related prokaryotic communities. Appl. Environ. Microbiol. 72: 4829-4838.

Ramsing NB, Kühl M and Jørgensen BB (1993). Distribution of sulfate-reducing bacteria, O2, and H2S in photosynthetic biofilms determined by oligonucleotide probes and microelectrodes. Appl. Environ. Microbiol. 59: 3840-3849.

Röske K, Röske I and Uhlmann D (2008). Characterization of the bacterial population and chemistry in the bottom sediment of a laterally subdivided drinking water reservoir system. Limnologica 38: 367-377.

Röske K, Sachse R, Scheerer C and Röske I (2012). Microbial diversity and composition of the sediment in the drinking water reservoir Saidenbach (Saxonia, Germany). Syst. Appl. Microbiol. 35: 35-44.

Saitou N and Nei M (1987). The neighbor-joining method: a new method for reconstructing phylogenetic trees. Mol. Biol. Evol. 4: 406-425.

Schippers A and Neretin LN (2006). Quantification of microbial communities in near-surface and deeply buried marine sediments on the Peru continental margin using real-time PCR. Environ. Microbiol. 8: 1251-1260.

Tamura K, Peterson D, Peterson N, Stecher G, et al. (2011). MEGA5: molecular evolutionary genetics analysis using maximum likelihood, evolutionary distance, and maximum parsimony methods. Mol. Biol. Evol. 28: 2731-2739.

Teske A, Ramsing NB, Habicht K, Fukui M, et al. (1998). Sulfate-reducing bacteria and their activities in cyanobacterial mats of Solar Lake (Sinai, Egypt). Appl. Environ. Microbiol. 64: 2943-2951.

Wagner M, Roger AJ, Flax JL, Brusseau GA, et al. (1998). Phylogeny of dissimilatory sulfite reductases supports an early origin of sulfate respiration. J. Bacteriol. 180: 2975-2982.

Wu XJ, Pan JL, Liu XL, Tan J, et al. (2009). Sulfate-reducing bacteria in leachate-polluted aquifers along the shore of the East China Sea. Can. J. Microbiol. 55: 818-828.

Xia BX, Song XL, Ding L, Jiang JC, et al. (2011). Determination of total phosphorus in marine sediments by microwave digestion-phosphorus vanadium molybdenum yellow spectrophotometry. Rock Mineral Anal. 30: 555-559.

Zhang H, Huang T and Liu T (2013). Sediment enzyme activities and microbial community diversity in an oligotrophic drinking water reservoir, eastern China. PLoS One 8: e78571.

Zhang W, Song LS, Ki JS, Lau CK, et al. (2008). Microbial diversity in polluted harbor sediments II: Sulfate-reducing bacterial community assessment using terminal restriction fragment length polymorphism and clone library of $d s r A B$ gene. Estuarine Coastal Shelf Sci. 76: 682-691.

Zhang Y, Su X, Chen F, Wang YY, et al. (2012). Microbial diversity in cold seep sediments from the northern South China Sea. Geosci. Front. 3: 301-316.

Zhou D, Wang DQ, Chen ZL, Sun YD, et al. (2009). Vertical profile and spatial distribution of acid-volatile sulfide in the estuarine and coastal sediments of Shanghai City. Res. Environ. Sci. 22: 138-144.

Zhu WH, Huang TL, Chai BB, Yang P, et al. (2010). Influence of the environmental conditions on the speciation of heavy metals in the reservoir sediment. Environ. Chem. 29: 629-635. 